\title{
Financial Ratios and Stock Returns on China's Growth Enterprise Market
}

\author{
Zhaohui Zhang ${ }^{1}$ \\ ${ }^{1}$ Finance Department, College of Management, LIU Post, 720 Northern Boulevard, Brookville, N. Y. 11548-1300, \\ USA
}

Correspondence: Zhaohui Zhang, Ph.D., Finance Department, College of Management, LIU Post, 720 Northern Boulevard, Brookville, N. Y. 11548-1300, USA. Tel: 516-299-2943. E-mail: zhaohui.zhang@liu.edu

Received: June 25, 2015

doi:10.5430/ijfr.v6n3p135

Accepted: July 10, $2015 \quad$ Online Published: July 13, 2015

URL: http://dx.doi.org/10.5430/ijfr.v6n3p135

\begin{abstract}
China's capital markets are not yet fully integrated into the world equity markets. Given the market segmentation, I investigate the relationships between financial ratios and short-term stock returns on China's recently established Growth Enterprise Market (GEM). Based on regression results, among dozens of financial variables tested, the year-to-year revenue growth is found to be the most significant variable predicting a stock's short-term performance in every sub-sample period. In contrast, neither the conventional measure price-to-book nor the newly proposed measure of gross profitability is significant. In addition, market capitalization does not behave in the familiar way found in developed markets. The evidence indicates that factors beyond the traditional size, value, or quality have strong explanatory power in short-term asset pricing behavior on the GEM.
\end{abstract}

Keywords: financial ratios, stock returns, Chinese GEM

\section{Introduction and Review}

China's capital markets are not integrated into the world equity markets due to restrictions on both cross-border capital controls (e.g., RMB is not freely convertible) and foreign ownership restrictions (QFII or Qualified Foreign Institutional Investors' combined quota about $\$ 94$ billion is less than 3 percent of A-shares' total market capitalization as of early 2014). (Note 1, Note 2). On June 9, 2014, according to Bloomberg, MSCI decided once again not to include A-shares into its Emerging Markets Index ( $\$ 1.3$ trillion market capitalization as of early June 2014). Given the market segmentation, opposing views exist in literature as to whether China's stock markets behave similarly to those markets in developed countries.

Elliott and Yan (2013) document extremely high average annual turnover rate in the Chinese stock markets during 2008-2012, average $341 \%$ (as high as $666 \%$ ) when only floating shares are considered, compared to the US rate of 188\%. Researchers (Xiao, 2006; Lim and Brooks, 2009; Chen, et al., 2010) examining stock valuations in China generally find little relationship to company fundamentals; investors tend to speculate more like noise traders in a casino fashion; and stock prices are less informative in China than they are in the U.S. Wu (2011) finds that neither size nor market factor matters in valuation, also the value effect is limited only for the SSE listed stocks. Goldstein, et al. (2013) show "theoretically that undesirable coordination across speculators makes the market less informative, decreases real investment, and increases stock market volatility."

However, Cakici, et al. (forthcoming) find strong predictive power of conventional measures such as size and book-to-market ratio, but not momentum indicators, consistent with developed market experience. Carpenter, Lu, and Whitelaw (2014) find that "Despite its segmented nature, China's equity market delivers a cross-sectional pattern of returns surprisingly similar to that found in other countries, with high premia for size, value, illiquidity, and right skewed payoffs."

To add more evidence to this debate, I investigate the asset pricing behavior on China's recently established Growth Enterprise Market (GEM). In particular, I study the relationships between firms' financial ratios and their short-term cross-sectional stock returns. China's Growth Enterprise Market (GEM), also called ChiNext, started trading on Oct. 30, 2009 when the first twenty-eight firms were listed. The GEM is the country's "own NASDAQ-style market to foster the growth of young, entrepreneurial type of high-growth high-risk companies" (Zhang and Chang, 2014). By the end of that year, thirty-six stocks in total were listed. The number of listed stocks increased to 153, 261, and 355 
by the end of 2010, 2011, and 2012, respectively. No IPOs were allowed in 2013 for any market in China. From June 1,2010 to the end of 2013, the GEM index returned 34\%, compared to the main board Shanghai A-share index of $-17.6 \%$. The contrast was more dramatic for the year of 2013 when the GEM returned $82.7 \%$ versus $-6.7 \%$ for the A-share index. By comparison, for the same year of 2013, excluding dividends, S\&P500 and NASDAQ returned $29.6 \%$ and $38.3 \%$, respectively.

Many explanations have been put forth in media (no academic study yet) as to why the significant divergence happened between the A-share market and the GEM. In this paper, I only attempt to investigate what drives the cross-sectional stock returns within the GEM market, from the company's financial perspectives. I run cross-sectional predictive regressions of stock returns on the lagged financial ratios to detect what aspects of a company contribute to the return differences inn the market. Ou and Penman (1989) conduct a pioneering examination of U.S. company fundamentals in order to predict firms' future earnings based on which long and short positions are formed. These positions are held from as short as 3 months to as long as 36 months. The strategy produces a significant market adjusted alpha of $14.5 \%$ over a 2 -year period.

In literature afterwards on developed markets, major financial ratios - size, dividend yield (DY), earnings yield (EY), and book-to-market $(\mathrm{B} / \mathrm{M})$ - have been found to have significant power predicting stock returns (Lewellen, 2004; Piotroski, 2000; Pontiff and Schall, 1998; Kothari and Shanken, 1997; Fama and French, 1998, 1993, 1992, 1988; etc.). The general consensus is that size and $\mathrm{B} / \mathrm{M}$ are sufficient to explain cross-sectional return differentials on equity markets. Also, the size effect is somewhat less significant in developing markets than in developed markets (Fama and French, 1998).

Fama and French (2008) show that profitability metrics are not significant in predicting cross-sectional stock returns. Most recently, however, Novy-Marx (2013) finds that "gross profitability" (gross profits scaled by assets) shows as much power forecasting cross-sectional stock returns as traditional value measures such as B/M. This profitability measure is also "far superior to the earnings in predicting returns." His study elevates the importance of quality metrics in investing to that of traditional value and growth metrics. We apply this ratio to our analysis of the Chinese markets in this paper.

I run the cross-sectional regression analysis to identify the common factors or financial ratios that explain the performance differentials between stocks listed on the GEM. The finding is that among the dozens of financial variables, the year-to-year revenue growth is the single most significant variable predicting a stock's short-term performance in every sub-sample period on GEM. In contrast, neither price-to-book nor gross profitability is significant when the year-to-year revenue growth is present. In addition, market capitalization does not behave in the familiar way shown in literature. The evidence seems to indicate that factors beyond the traditional size, value, or quality could have dominant explanatory power in short-term asset pricing behavior on this new market.

The paper is organized as follows. Section 2 presents the hypotheses. Section 3 explains the data and methodology, section 4 provides the empirical results. Section 5 offers concluding remarks and further tests to be attempted.

\section{Hypotheses}

In literature, for developed markets, it has been documented that market capitalization and price-to-book are significant and negatively related to stock returns. That is, small and undervalued stocks tend to outperform their counterparties. Gross profitability is positively related to stock returns. Also, investors can rationally expect firm fundamentals and thus price securities accordingly. For the first hypothesis, I test whether these variables are also significant in valuation on China's GEM.

As discussed in Introduction, China's stock markets have not been integrated into the world equity markets and conflicting evidence on valuation has been presented in the literature. For a future study, the SME being a segment of the traditional market that is the closest to the GEM in terms of market capitalization as well as non-state ownership, it can be used to examine whether the same financial ratios evidenced in the developed markets convey the same level of informedness to stock investors in China. Since the GEM has a much shorter history, further comparisons could be made first with the SME stocks for different horizons and the shortest of which matches that of the GEM market. The hypothesis there would be that SME stocks are valued similarly to the norms found in the more advanced markets. Also, there would be no difference between results from longer testing periods and those from the shorter period.

Given the present valuation on China's GEM, whether there is a logical relationship between financial ratios and the short-term cross-sectional stock returns? Is the relationship similar to that revealed in the mature market for the same period? In essence, are small entrepreneurial high-tech stocks valued similarly to those traditional stocks, given that 
the market capitalization and ownership structure are controlled? How would different factors, if any, between the two markets account for the stock performance?

\section{Data and Methodology}

Our data are from Bloomberg and Tong Daxin Database. Tong Daxin is one of the main stock market data vendors for China's trading platforms. The dataset consists of all the stocks in Growth Enterprise Market (GEM) on the Shenzhen Stock Exchange (SZSE) from 2012 to the end of 2013. The GEM is formed with the goal of nurturing the growth of early-stage innovative and high-tech oriented companies in the country. The stock exchanges in China are electronic limit order only markets with no specialists (or market makers). Also, there is a daily price limit of $10 \%$ (up or down) for each stock from the previous close. Short selling, still limited on selected stocks listed on the main boards, on the GEM, it is still prohibited. The SZSE operates 4 from 9:30 a.m. to 11:30 a.m. and from 1:00 p.m. to 3:00 p.m. each day, with a one-and-half-hour break during the soon.

The GEM listed about 350 stocks by the end of 2012. The total market capitalization was about RMB 872 billion (about US $\$ 140$ billion) at the same time. By the end of 2013, the total market capitalization had increased to about RMB 1.5 trillion (about US $\$ 248$ billion). Our initial sample consists of the cross-sections of the entire listed stocks on the GEM.

The financial variables of each stock are obtained initially at the end of 2012. However, the data used for calculation of ratios are traced back to 2011. For example, the year-over-year revenue growth rate provided at the end of 2012 is calculated as the revenue change between the second quarter of 2012 and the second quarter of 2011 divided by the 2011 Q2 revenue amount. Defined by Noxy-Marx (2013), the gross profitability is calculated as the revenue minus COGS divided by the total assets at the end of each period.

In addition, since all stocks' tickers are sequenced by the IPO time, e.g., ticker 300001 indicates it was the first firm chosen to be listed on the GEM, the year-over-year revenue growth may not be available for stocks listed after mid-2011. The regressions that included year-over-year revenue growth rate are run in two separate cases: one that has full sample of all stocks (about 340) and the reduced sample where tickers higher than 300304 are deleted due to nonexistence of data. The tradable market value is determined by the current price and the tradable number of shares outstanding. The ratio of a stock's tradable number of shares outstanding over its total number of shares outstanding ranges from $10 \%$ to $70 \%$, with an average of $38 \%$. The non-tradable shares have a locking period of three years after IPO. None of the shares faced locking period expiration during the sampling period. Tests conducted using total number of shares outstanding yield similar results and are not reported in the paper.

Zhang and Chang (2014) show the industry and market capitalization characteristics s of the companies listed on the GEM. Software stocks form the largest group, containing about 27 firms. The electrical parts and equipment industries have about 24 and 22 firms listed. Chemical materials, special machinery, and telecom industries have about 20 firms each, followed by semiconductor, electrical instrument, medicare, and pharmaceutical industries, having between 10 and 15 firms each. Other industries, such as environmental protection and internet, have fewer than 10 stocks listed each.

In terms of the market capitalization distribution of the sample firms, there are 102 firms that are smaller than RMB 2 billion, 140 firms between RMB 2 billion and RMB 4 billion, 84 firms between RMB 4 billion and RMB 10 billion, and 24 firms larger than RMB 10 billion. The mean and median market capitalization of all the firms are RMB 4.3 billion and RMB 2.9 billion, respectively.

The out-of-sample predictive regressions are run to identify from the literature documented key variables significantly affecting stock returns. These variables include minority interests, debt ratio, intangible assets, year-over-year earnings growth rate, year-over-year revenue growth rate, $\mathrm{P} / \mathrm{B}, \mathrm{P} / \mathrm{S}$, gross margin, net margin, floating market capitalization, total market capitalization, and gross profitability, etc. In order to grasp the underlying time varying factor impacts, the regression analyses are done on a quarterly and cumulatively extending forward. The same analyses then are done on a rolling quarterly basis. Inferences are drawn based on one quarter forecast ahead, half year forecast ahead, three quarters forecast ahead, and full year forecast ahead. (Note 3)

Matching stock returns with financial variables at different times, i.e., three or six months, is the convention and the tests are not affected because different firms may have reported accounting data with time gaps (e.g., Fama and French, 1992).

\section{Preliminary Results}

Regression results from the first quarter of 2013 are reported in Table 1. When market capitalization factor (measured by logarithm of the value of floating or tradable shares) is not used in the model, both the year-over-year revenue growth rate $(\mathrm{p}$-value $=0.0046)$ and $\mathrm{P} / \mathrm{B}(\mathrm{p}$-value $=0.0017)$ are significant at the $1 \%$ level and positively 
related to the cross-sectional stock returns. However, the larger the $\mathrm{P} / \mathrm{B}$, the higher the predicted return is for the quarter, in contrast to the developed market experience. Further, when market capitalization factor is added to the model, the year-over-year revenue growth rate $(\mathrm{p}$-value $=0.0067)$ is still significant at the $1 \%$ level and positively related to the cross-sectional returns, but $\mathrm{P} / \mathrm{B}$ becomes insignificant ( $\mathrm{p}$-value $=0.6939)$ and its impact is replaced by the market capitalization factor ( $\mathrm{p}$-value $=0.0000$ ) which is also positively related to stock returns, indicating that for the first quarter of 2013, larger firms performed better than others.

When gross profitability (measured at the year-end of 2012) alone is used in the regression, it is significant (p-value $=0.0160$ ) at the $5 \%$ level, but is negatively related to the cross-sectional stock returns (estimated beta $=-0.1963$ ). When the market capitalization factor is added to the model, the gross profitability is still significant at the 5\% level $(p$-value $=0.0384)$ with a negative estimated beta of $(-0.01573)$. However, when the year-over-year revenue growth rate but not market cap is added, gross profitability becomes no long significant (p-value $=0.6443$ ) at any conventional levels. The year-over-year revenue growth rate seems to dominate the gross profitability in terms of return forecasting.

In addition, the negative sign of gross profitability is opposite to the U.S. market experience (Novy-Marx, 2013), indicating that at similar gross margin levels, the larger the total asset base (or larger firms), the smaller the stock returns one quarter ahead, perhaps reinforcing the finding that larger firms outperformed smaller counterparties at least in the underlying quarter.

The overall finding is that the year-over-year revenue growth rate and market capitalization are both significantly and positively related to stock returns in the first quarter of 2013. They dominate other financial ratios in predicting returns for the quarter. $\mathrm{P} / \mathrm{B}$ and gross profitability are not significant when size and revenue growth are present.

Table 1. Predictive regression statistics for the first quarter of 2013

\begin{tabular}{|c|c|c|c|c|}
\hline \multirow[t]{3}{*}{ Panel A. } & R-square & F-value & P-value & \\
\hline & 0.0931 & 9.6180 & $0.0000 * * *$ & \\
\hline & Coeff. & S. E. & T-value & P-value \\
\hline Intercept & 0.0038 & 0.0456 & 0.0830 & 0.9339 \\
\hline YoY Rev\% & 0.0890 & 0.0311 & 2.8599 & $0.0046^{* * *}$ \\
\hline $\mathrm{P} / \mathrm{B}$ & 0.0295 & 0.0093 & 3.1614 & $0.0017 * * *$ \\
\hline \multirow[t]{3}{*}{ Panel B. } & R-square & F-value & P-value & \\
\hline & 0.1501 & 12.3643 & $0.0000 * * *$ & \\
\hline & Coeff. & S. E. & T-value & P-value \\
\hline Intercept & -0.7966 & 0.1899 & -4.1941 & 0.0000 \\
\hline YoY Rev\% & 0.0826 & 0.0302 & 2.7317 & $0.0067 * * *$ \\
\hline $\mathrm{P} / \mathrm{B}$ & 0.0042 & 0.0108 & 0.3940 & 0.6939 \\
\hline Ln(FMV) & 0.0792 & 0.0183 & 4.3333 & $0.0000 * * *$ \\
\hline \multirow[t]{3}{*}{ Panel C. } & R-square & F-value & P-value & \\
\hline & 0.0164 & 5.8626 & $0.0160 * *$ & \\
\hline & Coeff. & S. E. & T-value & $\mathrm{P}$-value \\
\hline Intercept & 0.1444 & 0.0189 & 7.6539 & 0.0000 \\
\hline Profit_4Q12 & -0.1963 & 0.0811 & -2.4213 & $0.0160 * *$ \\
\hline \multirow[t]{3}{*}{ Panel D. } & R-square & F-value & P-value & \\
\hline & 0.0615 & 9.2358 & $0.0001 * * *$ & \\
\hline & Coeff. & S. E. & T-value & P-value \\
\hline Intercept & 0.0906 & 0.0244 & 3.7058 & 0.0002 \\
\hline YoY Rev\% & 0.1224 & 0.0300 & 4.0762 & $0.0000 * * *$ \\
\hline Profit 4Q12 & 0.0668 & 0.1447 & 0.4622 & 0.6443 \\
\hline \multirow[t]{3}{*}{ Panel E. } & R-square & F-value & P-value & \\
\hline & 0.1500 & 16.5243 & $0.0001 * * *$ & \\
\hline & Coeff. & S. E. & T-value & P-value \\
\hline Intercept & -0.8252 & 0.1734 & -4.7603 & 0.0000 \\
\hline YoY Rev\% & 0.0824 & 0.0306 & 2.6967 & $0.0074 * * *$ \\
\hline Ln(FMV) & 0.0818 & 0.0157 & 5.2216 & $0.0000 * * *$ \\
\hline
\end{tabular}


Regression results for the first half of 2013 are reported in Table 2. When the year-over-year revenue growth, P/B, and gross margin are present, all three are significant at the 5\% level. However, when market capitalization is added, the year-over-year revenue growth and size are significant and positively related to returns at the $5 \%$ level, but gross margin is only significant at the $10 \%$ level. Gross profitability is not significant at any conventional level when market capitalization is present. Only the year-over-year revenue growth and market capitalization are significant at the $5 \%$ level when all five factors are present.

Table 2. Predictive regression statistics for the first half of 2013

\begin{tabular}{lllll}
\hline Panel A. & R-square & F-value & P-value & \\
& 0.0802 & 8.1649 & $0.0000^{* * *}$ & P-value \\
& Coeff. & S. E. & T-value & 0.5862 \\
Intercept & -3.6391 & 6.6779 & -0.5449 & $0.0372^{* *}$ \\
YoY Rev\% & 0.1402 & 0.0670 & 2.0932 & $0.0235^{* *}$ \\
P/B & 4.4931 & 1.9720 & 2.2784 & $0.0374^{* *}$ \\
GM\% & 0.2892 & 0.1383 & 2.0911 & \\
\hline Panel B. & R-square & F-value & P-value & \\
& 0.1059 & 11.0974 & $0.0000^{* * *}$ & P-value \\
& Coeff. & S. E. & T-value & 0.0005 \\
Intercept & -134.3315 & 38.1984 & -3.5167 & $0.0273^{* *}$ \\
YoY\% & 0.1408 & 0.0635 & 2.2183 & $0.0842^{*}$ \\
GM\% & 0.2370 & 0.1368 & 1.7328 & $0.0003^{* * *}$ \\
Ln(FMV) & 12.7877 & 3.4890 & 3.6651 & \\
\hline Panel C. & R-square & F-value & P-value & P-value \\
& 0.1097 & 6.8751 & $0.0000^{* * *}$ & 0.0050 \\
Intercept & Coeff. & S. E. & T-value & $0.0361^{* *}$ \\
YoY\% & -119.0509 & 42.0879 & -2.8286 & 0.3556 \\
P/B & 0.1442 & 0.0685 & 2.1062 & $0.0659^{*}$ \\
GM\% & 2.2204 & 2.3996 & 0.9253 & $0.0055^{* * *}$ \\
Ln(FMV) & 0.2850 & 0.1544 & 1.8461 & 0.3793 \\
Profit_4Q12 & 11.1902 & 4.0018 & 2.7963 & \\
\hline
\end{tabular}

Regression results for the first three quarters of 2013 are reported in Table 3. Unlike the previous results, both the year-over-year revenue growth rate and gross margin are significant at the $1 \%$ level throughout this sample period. Similar to previous findings, $\mathrm{P} / \mathrm{B}$ and gross profitability are not significant at any conventional level. However, market capitalization is no longer significant at any conventional level when the year-over-year revenue growth rate and gross margin are present. 
Table 3. Predictive regression statistics for the first three quarters of 2013

\begin{tabular}{|c|c|c|c|c|}
\hline \multirow[t]{3}{*}{ Panel A. } & R-square & F-value & P-value & \\
\hline & 0.0920 & 9.4933 & $0.0000 * * *$ & \\
\hline & Coeff. & S. E. & T-value & P-value \\
\hline Intercept & 19.9131 & 13.7540 & 1.4478 & 0.1488 \\
\hline YoY\% & 0.4890 & 0.1380 & 3.5444 & $0.0005 * * *$ \\
\hline $\mathrm{P} / \mathrm{B}$ & -0.8076 & 4.0616 & -0.1988 & 0.8425 \\
\hline GM $\%$ & 0.9475 & 0.2849 & 3.3261 & $0.0010 * * *$ \\
\hline \multirow[t]{3}{*}{ Panel B. } & R-square & F-value & P-value & \\
\hline & 0.0956 & 7.3963 & $0.0000 * * *$ & \\
\hline & Coeff. & S. E. & T-value & P-value \\
\hline Intercept & -62.1215 & 79.9714 & -0.7768 & 0.4379 \\
\hline YoY\% & 0.4673 & 0.1410 & 3.3146 & $0.0010 * * *$ \\
\hline GM $\%$ & 0.9146 & 0.3213 & 2.8466 & $0.0047 * * *$ \\
\hline Ln(FMV) & 7.5683 & 7.3337 & 1.0320 & 0.3030 \\
\hline Profit_4Q12 & -26.2610 & 69.3315 & -0.3788 & 0.7051 \\
\hline \multirow[t]{3}{*}{ Panel C. } & R-square & F-value & P-value & \\
\hline & 0.0970 & 5.9961 & $0.0000 * * *$ & \\
\hline & Coeff. & S. E. & T-value & P-value \\
\hline Intercept & -86.1130 & 87.6234 & -0.9828 & 0.3266 \\
\hline YoY\% & 0.4822 & 0.1428 & 3.3756 & $0.0008 * * *$ \\
\hline $\mathrm{P} / \mathrm{B}$ & -3.3792 & 5.0194 & -0.6732 & 0.5014 \\
\hline GM $\%$ & 0.9026 & 0.3221 & 2.8020 & $0.0054 * * *$ \\
\hline Ln(FMV) & 10.2333 & 8.3401 & 1.2270 & 0.2209 \\
\hline Profity_4Q12 & -6.6222 & 75.2807 & -0.0880 & 0.9300 \\
\hline
\end{tabular}

Regression results for the full year of 2013 are reported in Table 4. Similar to the first three quarters' results, both the year-over-year revenue growth rate and gross margin are significant at the 5\% significance level; market capitalization and gross profitability are not significant at the conventional significance level.

Table 4. Predictive regression statistics for the full year of 2013

\begin{tabular}{|c|c|c|c|c|}
\hline \multirow[t]{3}{*}{ Panel A. } & R-square & F-value & P-value & \\
\hline & 0.0571 & 5.6712 & $0.0009 * * *$ & \\
\hline & Coeff. & S. E. & T-value & P-value \\
\hline Intercept & 73.7142 & 67.2410 & 1.0963 & 0.2739 \\
\hline YoY\% & 0.3314 & 0.1117 & 2.9680 & $0.0033 * * *$ \\
\hline GM\% & 0.6064 & 0.2374 & 2.5540 & $0.0112 * *$ \\
\hline Ln(FMV) & -2.7425 & 6.1396 & -0.4467 & 0.6554 \\
\hline \multirow[t]{3}{*}{ Panel B. } & R-square & F-value & P-value & \\
\hline & 0.0439 & 4.2883 & $0.0056 * * *$ & \\
\hline & Coeff. & S. E. & T-value & P-value \\
\hline Intercept & 64.1802 & 67.7294 & 0.9476 & 0.3442 \\
\hline YoY\% & 0.2798 & 0.1190 & 2.3503 & $0.0195 * *$ \\
\hline Ln(FMV) & -0.8438 & 6.1329 & -0.1376 & 0.8907 \\
\hline Profity_3Q13 & 84.5606 & 52.4017 & 1.6137 & 0.1077 \\
\hline \multirow[t]{3}{*}{ Panel C. } & R-square & F-value & P-value & \\
\hline & 0.0589 & 4.3685 & $0.0019 * * *$ & \\
\hline & Coeff. & S. E. & T-value & P-value \\
\hline Intercept & 76.4522 & 67.5668 & 1.1315 & 0.2588 \\
\hline YoY\% & 0.3090 & 0.1191 & 2.5942 & $0.0100 * * *$ \\
\hline GM $\%$ & 0.5728 & 0.2715 & 2.1097 & $0.0358 * *$ \\
\hline $\operatorname{Ln}(\mathrm{FMV})$ & -3.1912 & 6.1962 & -0.5150 & 0.6069 \\
\hline Profity_3Q13 & 27.9980 & 58.5778 & 0.4780 & 0.6331 \\
\hline
\end{tabular}




\section{Conclusions}

This paper adds new evidence to the literature that equity valuation under market segmentation may be different from those mature market experience. Using the data from a relatively new market, I find that the year-to-year revenue growth is the most significant variable predicting a stock's short-term performance, holding others constant. In contrast, neither the conventional measure price-to-book nor the newly proposed measure of gross profitability is significant. In addition, market capitalization does not behave in the familiar way shown in developed markets. The evidence indicates that factors beyond the traditional size, value, or quality may have strong explanatory power in short-term asset pricing behavior in China's GEM. The caveat is that the results are found from a relatively small sample of a market that is new and has significant industry concentrations.

\section{References}

Asness, C.S., Moskowitz, T.J., \& Pedersen, L.H. (2013). Value and momentum everywhere. The Journal of Finance, 68, 929-985. http://dx.doi.org/10.1111/jofi.12021

Cakici, N., Chan, K., \& Topyan, K. (2015). Cross-sectional stock return predictability in China. European Journal of Finance, Forthcoming. http://dx.doi.org/10.1080/1351847X.2014.997369

Carpenter, J., Lu, F., \& Whitelaw, R. (2015). The Real Value of China's Stock Market. Working paper.

Chan, K., Menkveld, A.J., \& Yang, Z. (2008). Information asymmetry and asset prices: Evidence from the China foreign share discount. The Journal of Finance, 63, 159-196. http://dx.doi.org/10.1111/j.1540-6261.2008.01313.x

Chen, Qi, Goldstein, I., \& Jiang, W. (2007). Price informativeness and investment sensitivity to stock price. Review of Financial Studies, 20, 619-650. http://dx.doi.org/10.1093/rfs/hhl024

Chen, X., Kim, K.A., Yao, T., \& Yu, T. (2010). On the predictability of Chinese stock returns. Pacific-Basin Finance Journal, 18, 403-425. http://dx.doi.org/10.1016/j.pacfin.2010.04.003

Elliott, D., \& Yan, K. (2013). The Chinese financial system: An introduction and overview. John L. Thornton China Center Monograph Series.

Fama, E., \& French, K. (1988). Dividend yields and expected stock returns. Journal of Financial Economics, 22, 3-25. http://dx.doi.org/10.1016/0304-405X(88)90020-7

Fama, E., \& French, K. (1992). The Cross-Section of Expected Stock Returns. Journal of Finance, 47, 427-465. http://dx.doi.org/10.1111/j.1540-6261.1992.tb04398.x

Fama, E., \& French, K. (1993). Common risk factors in the returns on stocks and bonds. Journal of Financial Economics, 33, 3-56. http://dx.doi.org/10.1016/0304-405X(93)90023-5

Fama, E., \& French, K. (1998). Value versus growth: the international evidence. Journal of Finance, 53, 1975-1999. http://dx.doi.org/10.1111/0022-1082.00080

Fama, E., \& French, K. (2008). Dissecting Anomalies. The Journal of Finance, 63, 1653-1678. http://dx.doi.org/10.1111/j.1540-6261.2008.01371.x

Fama, E., \& French, K. (2012). Size, value, and momentum in international stock returns. Journal of Financial Economics, 105, 457-472. http://dx.doi.org/10.1016/j.jfineco.2012.05.011

Goldstein, I., Li, Y., \& Yang, L. (2014). Speculation and Hedging in Segmented Markets. Review of Financial Studies, 27, 881-922. http://dx.doi.org/10.1093/rfs/hht059

Kim, D. (1997). A reexamination of firm size, book-to-market, earnings price in the cross-section of expected stock returns. Journal of Financial and Quantitative Analysis, 32, 389-463. http://dx.doi.org/10.2307/2331233

Kothari, S.P., \& Shanken, J. (1998). Book-to-market, dividend yield, and expected market returns: A time-series analysis. Journal of Financial Economics, 44, 169-203. http://dx.doi.org/10.1016/S0304-405X(97)00002-0

Lewellen, J. (2004). Predicting returns with financial ratios. Journal of Financial Economics, 74, $209-235$. http://dx.doi.org/10.1016/j.jfineco.2002.11.002

Lim, K-P., \& Brooks, R. (2009). Are Chinese Stock Markets Efficient? Further Evidence from a Battery of Nonlinearity Tests. Applied Financial Economics, 19, 147-55. http://dx.doi.org/10.1080/09603100701765182

Noxy-Marx, R. (2013). The Other Side of Value: The Gross Profitability Premium. Journal of Financial Economics, 108, 1-28. http://dx.doi.org/10.1016/j.jfineco.2013.01.003 
Ou, J.A., \& Penman, S.H. (1989). Accounting Measurement, Price-Earnings Ratio, and the Information Content of Security Prices. Journal of Accounting Research, 27, 111-144. http://dx.doi.org/10.2307/2491068

Piotroski, J.D. (2000). Value Investing: The Use of Historical Financial Statement Information to Separate Winners from Losers. Journal of Accounting Research, 38, 1-41. http://dx.doi.org/10.2307/2672906

Pontiff, J., \& Schall, L. (1998). Book-to-market ratios as predictors of market returns. Journal of Financial Economics, 49, 141-160. http://dx.doi.org/10.1016/S0304-405X(98)00020-8

Rutledge, R.W., Zhang, Z., \& Karim, K. (2008). Is There a Size Effect in the Pricing of Stocks in the Chinese Stock Markets?: The Case of Bull versus Bear Markets. Asia-Pacific Financial Markets, 15, 117-33. http://dx.doi.org/10.1007/s10690-008-9074-0

Schrimpf, A. (2010). International stock return predictability under model uncertainty. Journal of International Money and Finance, 29, 1256-1282. http://dx.doi.org/10.1016/j.jimonfin.2010.03.005

Torous, W., Valkanov, R., \& Yan, S. (2004). On predicting stock returns with nearly integrated explanatory variables. Journal of Business, 77, 937-966. http://dx.doi.org/10.1086/422634

Wang, Y., \& Iorio, A.D. (2007). The cross-sectional relationship between stock returns and domestic and global factors in the Chinese A-share market. Review Quantitative Finance and Accounting, 29, 181-203. http://dx.doi.org/10.1007/s11156-007-0026-y

Wu, H. (2011). The Value and Size Effect - Are There Firm-Specific-Risks in China's Domestic Stock Markets?. International Journal of Economics and Finance, 3, 26-37. http://dx.doi.org/10.5539/ijef.v3n3p26

Xiao, F. (2006). Irrational Exuberance and Stock Market Valuations: Evidence from China. Journal of Post Keynesian Economics, 29, 285-308. http://dx.doi.org/10.2753/PKE0160-3477290206

Zhang, Z., \& Chang, T. (2014). Trade Size and the Cross Section of Stock Returns: Informed versus Noise Traders in the Chinese Growth Enterprise Market. International Journal of Business, 19, 322-335.

\section{Notes}

Note 1. In October 2014, China will start the Shanghai-Hong Kong Stock Connect program which for the first time allows domestic investors to trade directly the shares listed beyond mainland on Hong Kong Stock Exchange (HKSE). Conversely, foreign investors are also allowed for the first time to trade directly the shares listed on the Shanghai Stock Exchange (SSE) from Hong Kong. The trading volume under this program is capped at about $20 \%$ of the combined daily volume on the two exchanges.

Note 2. The QDII (Qualified Domestic Institutional Investors) program was introduced late 2007 and its quota is capped at $\$ 850$ billion as of September 2014. The utilization rate of the quota was $40 \%$ as of March 31, 2014.

Note 3. "Matching stock returns with financial variables at different times, i.e., three or six months, is the convention and the tests are not affected because different firms may have reported accounting data with time gaps" (e.g., Fama and French, 1992). 